\title{
Managing hepatitis $C$ in liver transplant patients with recurrent infection
}

\author{
This article was published in the following Dove Press journal: \\ Transplant Research and Risk Management \\ II September 2009 \\ Number of times this article has been viewed
}

\author{
Tim Zimmermann' \\ Gerd Otto ${ }^{2}$ \\ Marcus Schuchmann' \\ 'Department of Internal Medicine, \\ ${ }^{2}$ Transplantation Surgery, University \\ of Mainz, Germany
}

\begin{abstract}
Hepatitis $\mathrm{C}$ virus $(\mathrm{HCV})$ reinfection after liver transplantation (LT) and recurrent hepatitis $\mathrm{C}$ often lead to recurrent cirrhosis ( $\mathrm{RC})$. $\mathrm{RC}$ is one of the most frequent complications resulting in organ failure and early death after LT in HCV-positive patients with reported 5 -year rates from $20 \%$ to $40 \%$. As HCV-cirrhosis is one of the leading indications for LT, the therapeutic management is a central issue. To date, the best available therapy is a combination of pegylated interferon + ribavirin in patients with established recurrent hepatitis C proven by liver biopsy. Although increasing experience in using interferon therapy after LT has suggested better response rates, treatment is limited by a poor tolerability and high rates of severe side effects, necessitating lower doses or withdrawal of therapy. The extent to which dose reductions and the concomitant administration of growth factors affect virological response or prevent complications is still to be determined. Prospective clinical trials are mandatory to identify the best time point and schedule of antiviral treatment in transplant patients. Currently, therapeutic options need to be discussed for each individual patient. Therefore therapy should be carried out only in transplant centers with experience in managing hepatitis C after LT.
\end{abstract}

Keywords: hepatitis C, liver transplantation, recurrent infection, treatment

\section{Introduction to hepatitis $\mathbf{C}$ virus management in liver transplant patients and implications for graft survival}

Nearly 300 million people worldwide are chronically infected with the hepatitis $C$ virus (HCV) and $20 \%$ to $30 \%$ develop liver cirrhosis within 20 to 30 years. HCV-related end-stage cirrhosis is currently the leading indication for liver transplantation (LT). ${ }^{1,2}$ Unfortunately, LT does not cure the infection and HCV reinfection of the liver allograft occurs almost universally after LT. ${ }^{3-5}$ Liver allografts become infected during reperfusion in the operating room, and viral titers reach pretransplant levels within 72 hours. ${ }^{6} \mathrm{HCV}$ recurrence is favored by potent immunosuppression regimens. ${ }^{7.8}$

Once reinfection is established the severity of recurrent hepatitis $\mathrm{C}$ ranges from minimal to severe liver damage and can progress to clinical decompensation, graft loss, and subsequent death. ${ }^{9,10,11}$

Reinfected HCV positive patients show a lower 5-year survival after transplantation compared to $\mathrm{HCV}$ negative patients. ${ }^{12,13}$ The reason for the significantly worse survival in HCV-reinfected patients is recurrent cirrhosis (RC). ${ }^{14}$ The course of RC is accelerated in transplant recipients compared with immunocompetent patients, with reported 5-year rates of RC up to $28 \%$ compared with less than $5 \%$ in nontransplant patients. ${ }^{15,16}$ In liver
Correspondence: Marcus Schuchmann Department of Internal Medicine, Johannes Gutenberg University of Mainz, Langenbeck Str. I, 55I0I Mainz, Germany $\mathrm{Tel}+496131 \quad 177389$

Fax +49 6131 173435

Email schuchm@uni-mainz.de
(C) 2009 Zimmermann et al, publisher and licensee Dove Medical Press Ltd. This is an Open Access article which permits unrestricted noncommercial use, provided the original work is properly cited. 
transplant recipients, the 5-year risk for decompensation is $18 \% .{ }^{17} \mathrm{RC}$ occurs especially in patients infected with $\mathrm{HCV}$ genotype 1, which is the most common genotype in North America and Europe.

\section{Clinical courses of hepatitis C after LT}

The clinical course of HCV recurrence is highly variable and ranges from normal or near-normal serum aminotransferases with minimal inflammation on liver biopsy to rapidly progressive, cholestatic hepatitis with rapid fibrosis leading to $\mathrm{RC}$ and graft failure sometimes within the first year after LT. ${ }^{5,9}$ Fibrosing cholestatic hepatitis $\mathrm{C}$ is an uncommon but well-documented complication in liver transplantation, which occurs in $5 \%$ to $10 \%$ of patients 1 to 3 months after LT. Variables leading to this enormous range of severity of disease recurrence are not well understood. While most published data point to risk factors for fibrosis progression after LT, to date no predictive factors are known to identify patients at high risk for rapid RC. Early markers may include hepatic stellate cell activation and a hepatic venous pressure gradient of $6 \mathrm{mmHg}{ }^{18,19}$

\section{Diagnosis of recurrent hepatitis $C$}

Recurrent hepatitis $\mathrm{C}$ after LT may be difficult to diagnose clinically and may be confused with acute cellular rejection in the graft. Serum alaninaminotransferase (ALT) levels are often elevated. Diagnosis is based on HCV-RNA levels and liver biopsy to confirm the diagnosis, stage the disease (inflammation, fibrosis), and determine treatment. ${ }^{20}$ Even in a given biopsy, differentiation between rejection with hepatitis $\mathrm{C}$ and hepatitis $\mathrm{C}$ alone can be very difficult and clinical features must also be considered (eg, the degree of immunosuppression, previous rejection).

\section{Risk factors}

\section{Immunopathogenesis of $\mathrm{HCV}$ and recurrent} hepatitis $\mathrm{C}$

The specific CD4+ and CD8+ T cell responses to $\mathrm{HCV}$ appear to be important determinants of viral clearance during acute $\mathrm{HCV}$ infection and of the severity of histologic recurrence following liver transplantation. ${ }^{21,22}$ Patients with severe recurrence failed to develop immunoreactivity to HCV antigens.

Although virus-specific CD4+ and CD8+ T cells and antibody responses are induced in the first weeks of acute hepatitis $\mathrm{C}$, patients with chronic viral persistence go through a phase of incomplete viral control accompanied by a decline in $\mathrm{HCV}$-specific CD4+ $\mathrm{T}$ cell responses. In contrast, patients with self-limited acute hepatitis $\mathrm{C}$ maintained strong CD4+ T cells for many years following resolution of disease. ${ }^{23}$ Lucas et al have shown that loss of function, ie, secretion of IFN- $\gamma$ and proliferation, preceded the physical deletion of HCV-specific CD4+ T cells. ${ }^{24}$

Specific HCV T cell responses can be detected as early as 6 weeks to 3 months after LT. ${ }^{25,26}$ Strong CD4+ $\mathrm{T}$ cell responses have been reported to be associated with improved outcomes with less severe injury at 12 months post-transplant. ${ }^{26}$ Although $\mathrm{HCV}$-specific T cell responses have been demonstrated, the degree to which these responses mediate hepatocellular injury remains unclear, given the high rates of major histocompatibility complex (MHC) mismatching in $\mathrm{LT}^{27,28}$ Donor MHC-restricted HCV-specific $\mathrm{T}$ cell responses have been reported after LT, but the extent to which they contribute to HCV pathogenesis in this setting remains unclear. ${ }^{29}$ Although $\mathrm{HCV}$-specific antiviral responses may not correlate with histological outcome, it is possible that the frequency or function of CD4+ regulatory $\mathrm{T}$ cells may correlate with outcomes. Thus, the degree of regulation of inflammatory responses may play a role in the development of liver damage post-transplantation. Injury at the time of recurrent hepatitis is characterized by an activation of hepatic stellate cells (HSC), which has been shown to be associated with worse outcome at 12 months, with more fibrosis in patients who had early HSC activation at 4 months during acute recurrent hepatitis. ${ }^{18,30}$ In the first 6 months after LT higher viral loads seem to drive an enhanced proliferative, proapoptotic and profibrotic host response.

Recent advances in the field of HCV immunopathogenesis have expanded the understanding of immunoregulatory receptors on $\mathrm{T}$ cells, most notably the programmed death receptor 1 (PD-1) in the nontransplant setting, which has been described as a major mediator of CD8+ T cell exhaustion. ${ }^{31}$ In patients who achieved spontaneous viral clearance, PD-1 expression tended to decline or to disappear on virus-specific CD8+ T-cells, whereas in patients who developed chronic infection, PD-1 expression persisted at high levels. A correlation was established between the strength of PD-1 expression and viral load. ${ }^{32}$ PD-1 blockade was shown to restore $\mathrm{HCV}$-specific CD4+ T cell function and proliferation. ${ }^{33}$ In vitro studies using antigen-specific stimulation in the presence of PD-1 antibodies or antibodies against the ligand PD-L1 and PD-L2 led to restoration of IFN- $\gamma$ production by virus-specific CD8+ T cells. A recent study found that intrahepatic $\mathrm{HCV}$-specific CD8+ $\mathrm{T}$ cells from chronically $\mathrm{HCV}$-infected patients were highly PD-1 positive, profoundly dysfunctional, and unexpectedly 
refractory to $\mathrm{PD}-1 / \mathrm{PD}-\mathrm{L}$ blockade, in contrast to circulating PD-1-intermediate HCV-specific CD8+ T cells with responsiveness to $\mathrm{PD}-1 / \mathrm{PD}-\mathrm{L}$ blockade. ${ }^{34}$ This intrahepatic functional impairment was HCV-specific and directly associated with the level of PD-1 expression. Therefore, the responsiveness to $\mathrm{PD}-1 / \mathrm{PD}-\mathrm{L}$ blockade seems to depend on the compartmentalization (liver-peripheral blood).

These observations could offer new opportunities to manipulate virus-specific immune responses in vivo. To date, no data exist on the role of PD-1 in recurrent hepatitis $\mathrm{C}$ after LT.

\section{Clinical risk factors}

A number of clinical risk factors for patients with recurrent hepatitis $\mathrm{C}$ have been reported:

The strongest predictor of outcome is donor age. In contrast to non-HCV infected patients, who show no survival disadvantage with grafts from donors aged 60 to 80 years, $\mathrm{HCV}$ recurrence is more severe when older donors are used. ${ }^{14,35-39}$

The influence of human leukocyte antigen mismatches on the severity of disease recurrence following LT remains controversial. ${ }^{40,41}$ No sites of mismatches associated with disease recurrence have been identified.

The type of donor used may affect patient and graft survival. More severe HCV-recurrence was reported in patients who underwent adult-to-adult living donor liver transplantation, whereas larger studies did not confirm this finding. ${ }^{42-50}$ A multicenter living donor liver transplant cohort revealed that the experience of the transplant center may be the driving factor in predicting patient outcomes. ${ }^{51}$ Patient and graft survival did not differ among recipients of living or deceased organs in centers that had performed at least 20 living donor transplants.

The influence of HCV genotype on the severity of disease recurrence in genotype 1 and non-1 patients following LT is controversial, too. ${ }^{40,41,52-55}$

The degree of divergence of HCV quasispecies seems to be enhanced in patients with severe recurrent hepatitis $C .{ }^{56}$

Within 72 hours after LT, serum HCV-RNA levels increase from 4- to 100 -fold. ${ }^{57}$ A relationship between pretransplant viral load and viral load after LT on graft and patient survival seems possible. Whether the pretransplant $\mathrm{HCV}$ viral load influences the severity of $\mathrm{HCV}$ recurrence is discussed. ${ }^{52,54,58} \mathrm{~A}$ high viral load correlates with severe hepatitis $\mathrm{C}$ recurrence and is associated with an activation of inflammatory, profibrotic, and proapoptotic pathways, whereas the grade of inflammation in the native liver at the time of LT and the time of recurrence are not predictive for progression of hepatitis C after LT. ${ }^{59-61}$

In summary high titers of HCV-RNA in the explanted liver as well as after LT may be risk factors for increased histological activity and fibrosis..$^{57,62,63}$

Since viral and immunological activity are closely linked to each other, the level and type of immunosuppression and treatment of acute rejections after LT influence the severity of disease recurrence. ${ }^{54,64,65}$

\section{Immunosuppression}

Immunosuppression is one of the major factors that accelerate the course of HCV recurrence. High-dose bolus steroids, rapid steroid tapering, and monoclonal antibody preparations such as OKT3 to treat acute rejection affect the progression of recurrent hepatitis $\mathrm{C}$ and should be avoided if possible. ${ }^{39,54,64-70}$

Although some studies have reported antiviral effects of cyclosporine and a shorter time of HCV recurrence after LT when using tacrolimus, there are no prospective, randomized controlled trials showing differences between cyclosporin and tacrolimus in their effect on $\mathrm{HCV}$ recurrence. ${ }^{69,71-73}$ In one prospective study there was no difference between calcineurin inhibitors during the first year after LT, although the time to acute hepatitis was significantly shorter in the tacrolimus group. ${ }^{68}$

Use of mycophenolate mofetil (MMF) has been debated: although MMF in combination with tacrolimus and steroids was associated with improved long-term patient and graft survival and lower rates of acute rejection, MMF did not show significant histological benefit on HCV recurrence. ${ }^{8,74}$

To date there are no convincing data to support the use of any specific induction or maintenance regimen.

A meta-analysis and meta-regression of 30 publications representing 19 randomized trials that compared steroid-free with steroid-based immunosuppression, showed that $\mathrm{HCV}$ recurrence was lower with steroid avoidance. ${ }^{75}$ In studies in which steroids were replaced by other immunosuppressive agents, the risks of diabetes and rejection were markedly lower in steroid-free arms. In studies in which steroids were not replaced, rejection rates were higher in steroid-free arms. ${ }^{75}$ In a prospective, randomized trial of 198 LT patients treated with basiliximab and cyclosporine, either in combination with prednisone or without prednisone, immunosuppression without steroids in HCV patients was safe with a lower rate of bacterial infections and metabolic complications. ${ }^{76}$ Histological short-term evolution of HCV recurrence was favorable, with lower fibrosis scores compared with the 
steroid group, whereas another study found no impact on hepatic fibrosis progression. ${ }^{76,77}$ In conclusion, avoiding steroids by induction with interleukin-2 receptor antibodies (ie, basiliximab) seems to be safe while eliminating some of the negative consequences and side effects associated with steroids. $^{78}$

\section{Therapy}

In terms of severity of recurrent hepatitis $\mathrm{C}$, it seems reasonable to treat hepatitis $\mathrm{C}$ after liver transplantation, particularly since rates of sustained virological response (SVR) with pegylated interferon and ribavirin in the $\mathrm{HCV}$-infected nontransplanted population are acceptable. ${ }^{79}$ However, patients with HCV reinfection of the graft usually have higher viral loads and harbor genotype 1 more prevalently than immunocompetent patients; both factors are predictive for a lower virological response rate. ${ }^{80-83}$ Moreover, many patients had been treated before transplantation with previous treatment failure and relapse.

Antiviral therapy has been occasionally associated with severe rejection of the graft and the general condition of many patients prevents the option of treatment, eg, due to infectious postoperative complications, anemia, and renal failure. ${ }^{84-86}$ The optimal time for treatment start, dosage, and duration after LT are still undefined. Different immunosuppressive regimens, induction therapies, use of steroids, dose reduction protocols, and antiviral therapeutic strategies are still debated.
Published data on the effect of treatment regimens on recurrent hepatitis $\mathrm{C}$ and $\mathrm{RC}$ progression are difficult to interpret, the results varying according to genotype, selection processes, inclusion criteria, and pretreatment strategies. Remarkable differences in SVR rates between 14\% and $50 \%$ are reported (Figure 1). The available therapies do not solve the clinical problems of RC since there is only evidence for survival benefit in patients who show a virological response. ${ }^{87,88}$

Nevertheless, management of chronic hepatitis $\mathrm{C}$ in LT recipients with recurrent hepatitis $\mathrm{C}$ has improved significantly during the past decade. ${ }^{88-111}$ The best results were obtained with pegylated interferon (PEG-IFN) alfa in combination with ribavirin, with higher SVR rates compared to IFN or ribavirin monotherapies. ${ }^{93}$

One of the main problems is to find the individual balance between tolerable and manageable side effects and maintain therapy over the whole time of treatment to maximize the number of SVR and minimize the number of relapsers.

Strategies to prevent HCV-recurrent cirrhosis and manage hepatitis $\mathrm{C}$ after LT are reviewed and discussed below.

\section{Overview of available agents to manage infection}

Strategies for managing HCV recurrence can be separated into pre-, peri-, and post-LT periods. Figure 2 presents an overview of the different timepoints and options for therapeutic intervention.

\section{SVR (\%)}

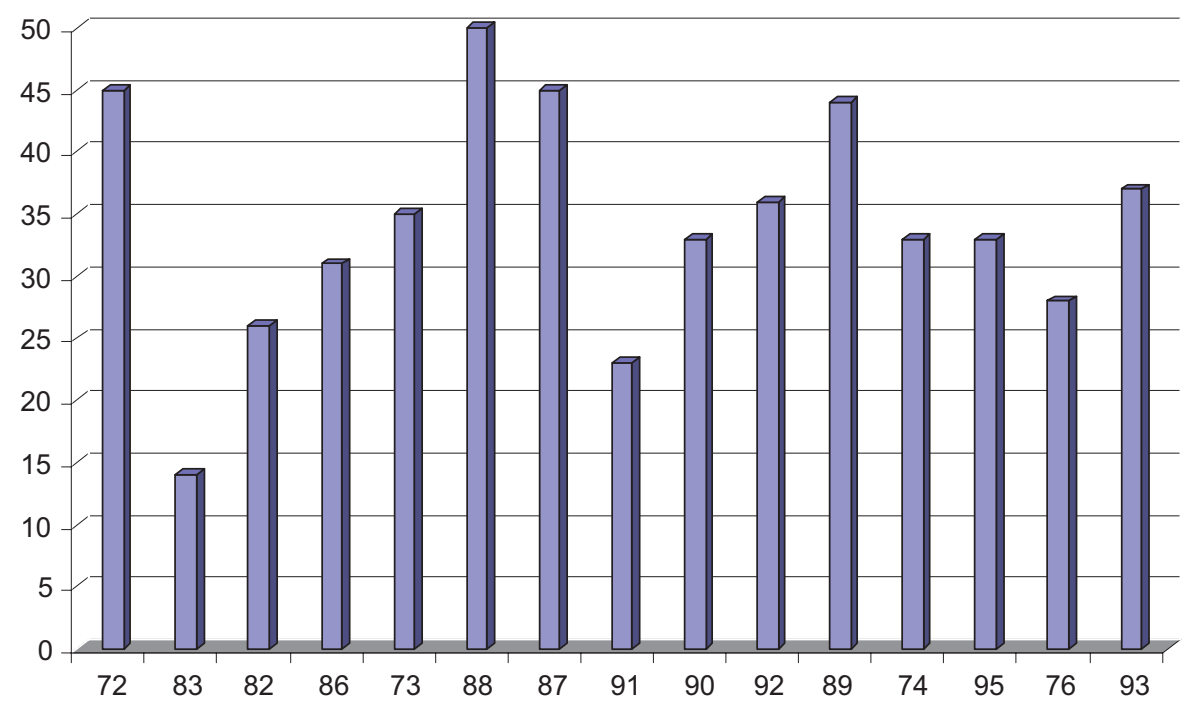

\section{References}

Figure I Sustained virological response (SVR) rates in studies with pegylated IFN $\alpha$ and ribavirin after diagnosis of recurrent hepatitis C. 


\section{Therapy before LT Prevention of reinfection}

\section{Therapy after LT}

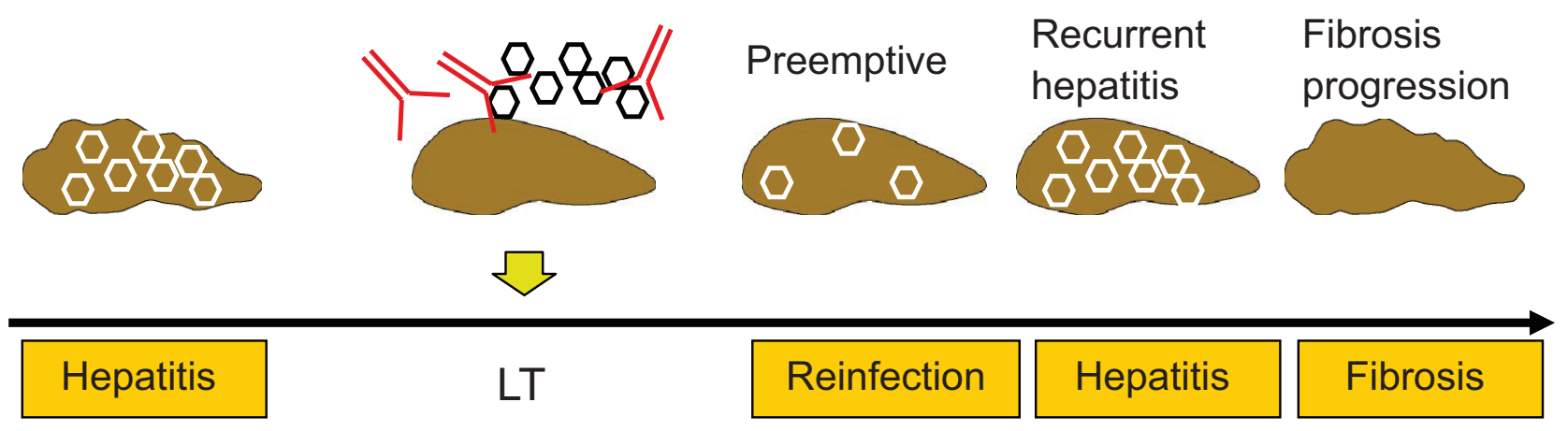

Figure 2 Treatment strategies.

Abbreviation: LT, liver transplantation.

\section{Therapy before LT}

The aim of this strategy is to render patients free of HCV-RNA before going into LT. Guidelines for the treatment of adult patients with hepatitis $\mathrm{C}$ in the nontransplant setting were published by the American Association for the Study of Liver Diseases (AASLD) and were recently updated. ${ }^{112,113}$ Treatment duration and dosage depends on the genotype and the virological response. Patients with genotype 1 are treated with PEG-IFN + ribavirin $(1000 \mathrm{mg} /$ day $\leq 75 \mathrm{~kg}$; $1200 \mathrm{mg} /$ day $>75 \mathrm{~kg}$ ). When there is a complete early virological response (EVR), as indicated by negative HCV-RNA at week 12, the treatment is continued for a total of 48 weeks. In case of a partial EVR (HCV-RNA declines $>2 \log$ ) HCV-RNA is determined at week 24; if negative, treatment is continued for 48 weeks, if positive, treatment will be discontinued. If there is no EVR (HCV-RNA $\downarrow \leq 2 \log$ ) at week 12 , treatment is stopped.

In genotype 2 or 3 patients treatment is carried out with PEG-IFN + ribavirin $(800 \mathrm{mg} /$ day $)$ for 24 weeks.

Recent data in the non-transplant setting suggest, that in patients with pretreatment low viral load $(<800,000 \mathrm{IU} / \mathrm{mL})$ and rapid virological response (RVR) duration of therapy can be reduced. ${ }^{114}$

Eradication of HCV infection prior to transplantation would be the ideal approach as patients who undergo transplantation in the absence of viremia are much less likely to have recurrent infection. However, treatment of patients with cirrhosis on the waiting list is very difficult and can be dangerous in the setting of decompensated liver function, exacerbation of encephalopathy, infections (spontaneous bacterial peritonitis), thrombocytopenia with bleedings, and other serious complications. Previous studies showed low rates of viral clearance. ${ }^{115,116}$ Everson et al treated 124 patients with advanced HCV cirrhosis with PEG-IFN + ribavirin with an overall SVR of $22 \%$. Genotype was an important determinant of response (SVR rate of $60 \%$ among patients with genotype 2 or 3 and $11 \%$ among patients with genotype 1). ${ }^{117}$ To date there is no consensus about dosing and optimal treatment regimen. Dose reductions are frequent due to low blood count levels and renal failure.

The lower tolerability in patients with decompensated cirrhosis on the waiting list and the elevated risk of severe side effects in this patient group limit therapeutical options. Therefore, according to International Liver Transplantation Society Consensus Panel, treatment is not advised for patients with a Child-Turcotte-Pugh (CTP) score of $\geq 11$ or a model for end-stage liver disease (MELD) score of $\geq 25 .{ }^{118}$

\section{Perioperative therapy (hepatitis $C$ immunoglobulin)}

Unlike hepatitis B, no effective immunoglobulin prophylaxis exists for hepatitis C. Studies evaluating HCV-specific immunoglobulins in vivo have produced inconclusive results. An initial report demonstrated that anti-HCV containing hepatitis B immunoglobulin reduced HCV reinfection in HBV/HCV co-infected liver transplant patients. ${ }^{119}$ However, a randomized, controlled trial of hepatitis $\mathrm{C}$ immunoglobulin to prevent recurrent hepatitis $\mathrm{C}$ did not find any substantial benefit. ${ }^{120}$ One possible explanation is that nonneutralizing antibodies contained in the polyclonal preparations may interfere with the function of neutralizing antibodies. ${ }^{121} \mathrm{To}$ date different experimental immunoglobulin preparations are in various stages of testing. Further studies are necessary and underway. ${ }^{120,122}$ 


\section{Therapy after LT}

\section{Preemptive therapy}

After LT two treatment strategies have been tried: preemptive antiviral therapy soon after LT, and treatment of patients after histological evidence of recurrent HCV (Figure 2). The aim of a preemptive therapy is to render patients' HCV viral load negative or to minimize recurrent hepatitis $C$. Interferon-based regimens have been tested, as interferon monotherapy ${ }^{123-125}$ or a combination of interferon and ribavirin, ${ }^{126}$ peginterferon alone ${ }^{127}$ or in combination with ribavirin. ${ }^{128,129}$ Although PEG-IFN alpha- $2 \mathrm{a}^{127}$ or $-2 \mathrm{~b}^{128}$ plus ribavirin were safe and well tolerated, the efficacy was very low, with SVR rates of $8 \%{ }^{127}$ and $18 \% .^{128}$

Preemptive therapy is initiated within 2 to 6 weeks after transplantation. During this time tolerability of therapy, particularly ribavirin, is often low and anemia leads to dose reductions or discontinuations of ribavirin. ${ }^{130}$ In one study only $35 \%$ (44/124) of transplant recipients were able to initiate prophylactic therapy. ${ }^{128}$ Reasons for ineligibility included anemia, acute rejection, infectious complications, renal failure, and myocardial infarction. Many patients are in the early post-transplant period simply "too sick" to tolerate therapy, resulting in very low SVR rates. The decision to treat is made on a patient by patient basis.

In summary, preemptive therapy and prophylactic treatment of patients transplanted for HCV-related cirrhosis are not generally recommended. The only current indications for preemptive therapy today are in retransplanted patients for rapidly progressive recurrent $\mathrm{HCV}$ and $\mathrm{HCV}$-negative transplant recipients who receive allografts from $\mathrm{HCV}$-positive donors. ${ }^{118}$

\section{Therapy of recurrent hepatitis $C$}

Treatment is initiated if recurrent hepatitis $\mathrm{C}$ is associated with significant liver injury as proven by biopsy (Desmet fibrosis score $\geq 2$ ). In the past decade many studies have been published dealing with this topic, but there are only very few prospective randomized studies. ${ }^{131,132}$ Most studies have been single-center trials with small numbers of patients with varying numbers of genotype 1/non-1 and different proportions of previous nonresponders.

In addition, to reduce the immunosuppressive regimens, specific treatment for HCV recurrence is based on interferon, ribavirin, and combination therapy.

\section{Interferon monotherapy}

Trials with interferon monotherapy showed little efficacy. ${ }^{84,133-135}$ Patients showed no significant improvement in histology.
Even with PEG-IFN, SVR rates were low (12\%), although patients had significantly lower HCV-RNA levels compared with untreated controls. ${ }^{127}$

\section{Ribavirin monotherapy}

Ribavirin monotherapy demonstrated poor efficacy without virological response. ${ }^{136,137}$ The necessity for dose reductions after LT due to poor tolerability related to calcineurin inhibitor-induced reduced glomerular filtration rate may contribute to its decreased efficacy. Since ribavirin monotherapy lacks efficacy even in the nontransplant setting, monotherapy has been abandoned.

\section{Standard interferon plus ribavirin}

Combination therapy with standard IFN and ribavirin resulted in SVR rates of over $20 \%$ in some studies, but up to $50 \%$ of patients drop out due to side effects, mainly anemia. $^{91-93,98,127,138-144}$

\section{PEG-IFN plus ribavirin}

Best treatment responses were obtained with the combination of PEG-IFN and ribavirin. ${ }^{93-96,98,99,102,105,106,109,110,127,145,146}$

Most published studies are uncontrolled trials with a high variability in patient selection, and type and timing of antiviral therapy. Rates of SVR have been less than those achieved in the nontransplant setting. Reasons were a higher viral load after LT, a higher frequency of genotype 1 patients, poor tolerability of treatment after LT, and need for frequent dose reductions. The current SVR rate with this regimen is $30 \%$, ranging from $12 \%$ to $43 \%$ in small studies. ${ }^{93-96,100,101,104,105}$ A meta-analysis from over 40 treatment trials estimated that SVR rates of combination therapy were $24 \%$ and $27 \% .{ }^{147}$ A recent systematic review of predominantly therapeutic intervention studies by Berenguer et al confirmed that $30.2 \%$ of patients treated with PEGIFN plus ribavirin will attain SVR. ${ }^{131}$ Dose reductions and discontinuation of treatment were common in these studies: $73 \%$ and $27.6 \%$, respectively.

\section{Fibrosis progression and impact of therapy on long-term outcome}

Divergent data have been reported for fibrosis progression under IFN treatment. Samuel et al randomized 52 patients to treatment of $\mathrm{HCV}$ recurrence with IFN alpha-2b plus ribavirin at standard doses $(n=28)$ or no treatment $(n=24)$ for 12 months. ${ }^{92}$ Treatment resulted in an SVR of $21 \%$ without significant histological improvement between the treatment and control groups. Another study reported marked histological improvement in $86 \%$ of patients with SVR achieved 
after 6 months of combined therapy, followed by 6 months of ribavirin. ${ }^{148}$ Little impact on fibrosis has been observed by others. ${ }^{149}$

Antiviral long-term medication is discussed controversely. In the non-transplant setting a subanalysis of the EPIC3-study, including 631 patients with liver cirrhosis and previous failure of IFN therapy, treated with $50 \mu \mathrm{g}$ PEG-IFN, revealed no benefit for IFN long-term medication in prevention of hepatic decompensation.

Only patients who achieve SVR by antiviral therapy show significantly improved long-term outcomes with better 5-year survival rates..$^{87,88,150}$

Since steatosis and the metabolic syndrome are associated with fibrosis progression and post-LT diabetes mellitus (PTDM), metabolic syndrome should be treated. ${ }^{151,152}$ Avoiding steroids may improve the metabolic syndrome, the rate of fibrosis progression, and the incidence of PTDM. Hyperglycemia, hypertension, and body mass index can be reduced by physical exercise and diet.

\section{Retransplantation}

Indications for retransplantation due to disease recurrence remain unclear and differ among institutions. The prognosis for these patients is poor in comparison with the first transplantation. ${ }^{153-160}$ Many patients are not considered eligible for retransplantation and die from recurrent disease and its complications, but there are no recommendations or guidelines about retransplantation in these patients. The option of retransplantation is discussed on an individual base.

\section{Factors affecting therapy Duration of IFN therapy}

There is no general recommendation for the duration and dosage of interferon therapy. Berenguer et al found that the strongest predictive factor of nonresponse is the lack of an EVR 3 months after start of therapy. ${ }^{131}$ For chronic hepatitis $\mathrm{C}$ in the nontransplant setting guidelines recommend that for patients who do not respond to therapy by week 12 (EVR with negative HCV-RNA or at least a $2 \log _{10}$ decrease from HCV-RNA at baseline), treatment should be discontinued because studies show that the negative predictive value of EVR is $97 \%$ to $100 \%$. $^{112}$ Whether this 12-week stopping rule applies equally to transplant recipients with recurrent hepatitis $\mathrm{C}$ has not been conclusively determined, but data from recent studies suggest that the role of EVR in predicting treatment outcome among liver transplant recipients is comparable to that in the nontransplant setting. ${ }^{104,106,107,110}$ EVR represents an important predictor of treatment outcome and may be considered a reliable indicator that treatment should be stopped if it is not attained. At present, attainment of EVR is the only factor shown by multivariate analysis to be significantly associated with SVR. ${ }^{101}$

Very few studies deal with the value of RVR in predicting treatment outcomes after LT. Hanouneh et al reported that RVR (defined as undetectable HCV RNA at week 4 of treatment) was a highly reliable predictor of treatment outcomes: all patients with undetectable HCV-RNA at week 4 attained SVR. ${ }^{161}$

Treatment with PEG-IFN plus ribavirin was administered in most studies over a duration of 12 months. ${ }^{94,96,98,99,101,104-110}$

The question of whether genotype 2 and 3 can be treated for a shorter time or if it is necessary to prolong therapy in patients with delayed virological response and high baseline viral loads as recommended in the nontransplant setting remains also to be answered. In the transplant setting many studies pool genotype 1 and non-1, resulting in higher overall SVR rates, since genotype 2 and 3 are known to result in better SVR rates. ${ }^{161}$

\section{Ribavirin dosing}

After LT, ribavirin has to be carefully administered because transplant recipients are particularly susceptible to ribavirin-induced toxicity, predominantly hemolytic anemia, which is reported in $70 \%$ to $100 \%$ of treated patients. ${ }^{104,106,107,109}$ Thus it is difficult to balance the necessity for high-dose ( $>800 \mathrm{mg}$ /day) ribavirin to attain high SVR rates against its extremely poor tolerability profile in these patients. Weight-based dosing is inadvisable because of the high treatment-related toxicity. Therefore many authors initiate ribavirin at low doses (400 to $600 \mathrm{mg} /$ day) and slowly escalate according to toxicologic parameters (hemoglobin levels, renal insufficiency, creatinine clearance, and overall tolerability) over a period of several (usually 4) weeks. ${ }^{104,108-110}$

\section{Dose reductions, discontinuations and use of growth factors}

Berenguer et al systematically analyzed studies evaluating antiviral therapies with PEG-IFN alpha in combination with ribavirin for the management of recurrent hepatitis $\mathrm{C}$ after LT. ${ }^{131}$ In 19 studies including 644 patients PEG-IFN alpha-2b was used in 16 studies: dose reductions were necessary in $73 \%$ of patients, and discontinuations occurred at $27.6 \%$ (mean SVR rate $30.2 \%$ ). 
The main causes of treatment discontinuation include cytopenia (particularly anemia), neuropsychiatric conditions, thyroid abnormalities, poor tolerability, and rejection episodes. ${ }^{131}$

Most transplant centers use growth factors to minimize the need for dose reductions or discontinuations. In 13 studies, where erythropoietin (EPO) was used, the overall SVR rate was 33\% and was not statistically different from the rate of $29 \%$ described in 5 studies where it was not used. ${ }^{131}$ The granulocyte colony-stimulating factor filgrastim was given in 11 studies with a SVR of $34 \%$ compared to $29 \%$ in 7 in which it was not administered. Although the absolute SVR rates did not statistically differ, the authors concluded that there was a trend to better results, both in terms of SVR and rate of discontinuation, over time: the rate of SVR was $19.7 \%$ in studies published in 2004 and 2005 compared to $35.2 \%$ studies published in 2006 and 2007.

These results may reflect a learning process in managing therapy of recurrent hepatitis $\mathrm{C}$ after LT with a greater use of growth factors.

EPO and growth factors may be useful to ensure that patients receive adequate antiviral therapy over time and minimize the number of dose reductions and discontinuations.

Furthermore, thrombopoietin receptor agonists, such as eltrombopag, may be useful for improving pretreatment platelet counts in patients with hepatitis $\mathrm{C}$ and cirrhosis who would otherwise be ineligible for therapy. ${ }^{162}$

\section{Safety and tolerability}

There is evidence that IFN therapy may enhance the likelihood of early acute graft rejection, with reported acute rejection rates up to $35 \%$ and chronic rejection rates up to $4 \%{ }^{46}$ However, controlled trials show no differences in rejection rates between untreated and treated recipients. ${ }^{127,128}$ Furthermore IFN has been reported to induce immune-mediated cryptogenic hepatitis. ${ }^{163,164}$

The tolerability of IFN treatment in combination with ribavirin is low and therefore dose reductions and discontinuation of treatment mainly due to hematologic toxicity and cytopenia are frequent. ${ }^{131}$ For patient-focused perspectives such as quality of life (QoL) or patient satisfaction, there are no published data for HCV-positive patients after LT, possibly due to the fact that these patients form a very heterogenous group with numerous pathologies. Among the HCV-positive nontransplant population the effects of IFN-induced depression and anemia on QoL are strong. ${ }^{165}$ Despite a reduced QoL under IFN therapy, many transplant patients are highly motivated after LT.

\section{Future perspectives}

\section{Specifically targeted antiviral therapy} for HCV (STAT-C)

A broad set of new antiviral therapies is on the horizon, whereas new drugs, directly targeting HCV replication, have already demonstrated promising results. Directly acting antiviral agents are collectively described as Specifically Targeted Antiviral Therapy for HCV (STAT-C). Orally available small molecules, which specifically inhibit the HCV genotype 1 nonstructural (NS) 3/4A serine protease and NS5B RNA-dependent RNA polymerase, have advanced to phase 2 and 3 clinical development respectively.

The HCV-specific proteinase inhibitors telaprevir (VX-950) and boceprevir (SCH503034) are the most advanced drugs and have been investigated in the nontransplant setting in combination with PEG-IFN and ribavirin.

Telaprevir forms a covalently but reversibly bound complex with HCV protease. A $4.4 \log _{10}$ median reduction in viral load at day 14 of treatment has been shown in patients given $750 \mathrm{mg}$ telaprevir every 8 hours, and an additional logarithmic reduction has been shown for telaprevir in combination with PEG-IFN. ${ }^{166}$ The PROVE 1 (USA) and 2 (Europe) studies (telaprevir) included therapy-naive patients with genotype 1 $(n=250 / 332)$, who were randomized in 4 treatment arms: PEG-IFN alpha-2a + ribavirin 1000 to $1200 \mathrm{mg}$ for 48 weeks; telaprevir $750 \mathrm{mg}$ (q8 h) + PEG-IFN + ribavirin for 12 weeks, followed by PEG-IFN + ribavirin for 12 weeks; telaprevir $750 \mathrm{mg}$ (q8 h) + PEG-IFN + ribavirin for 12 weeks; telaprevir $750 \mathrm{mg}$ (q8 h) + PEG-IFN for 12 weeks. ${ }^{167,168}$ Patients treated with telaprevir plus PEG-IFN and ribavirin for 12 weeks followed by PEG-IFN + ribavirin for 12 weeks showed higher SVR rates $(61 \% / 62 \%)$ compared to standard therapy, but the treatment was accompanied by a higher rate of side effects (PROVE 1: 13\% vs 3\%); especially rash or pruritus, gastrointestinal events, and anemia occurred more frequently. ${ }^{167,168}$

Boceprevir is the focus of a large study (SPRINT-1; $\mathrm{n}=595$ treatment-naive patients with genotype 1) with a complex design comparing standard therapy (PEG-IFN + ribavirin 800 to $1400 \mathrm{mg} /$ day, 48 weeks) with 5 different treatment regimens of boceprevir $(800 \mathrm{mg} /$ day): 4 weeks PEG-IFN + ribavirin lead-in followed by PEG-IFN + ribavirin ( 800 to $1400 \mathrm{mg} /$ day) + boceprevir for 24 or 44 weeks; PEG-IFN + ribavirin (800 to $1400 \mathrm{mg} /$ day) + boceprevir for 28 or 48 weeks; PEG-IFN + low dose ribavirin 
(400 to $1000 \mathrm{mg} /$ day) + boceprevir for 48 weeks. Best results were obtained in the group with lead-in-phase followed by 48 weeks of triple therapy. SVR rates reached $75 \%$ in this treatment group compared with 38\% under standard therapy. Boceprevir regimens significantly increased SVR with very low relapse rates.

Other nucleoside inhibitors and nonnucleoside, allosteric inhibitors of polymerase activity, have shown evidence of antiviral activity and are currently in clinical phase 1 and 2 studies (eg, ITMN-191, GSK625433, GS9190, R7128, TMC435350, R1626, VCH-759).

\section{Host factor-targeting drugs}

Besides STAT-C, host factor-targeting drugs and immunmodulatory approaches have been developed.

\section{Cyclophilin inhibitors}

The antiviral activity of nonimmunosuppressive cyclosporin analogs (NIM811; DEBIO-025) is also being investigated. These molecules disturb interaction of the replicase with cyclophilin $\mathrm{B}$, a functional regulator of the $\mathrm{HCV}$ RNA-dependent RNA polymerase that is independent of the calcineurin-nuclear factor of activated $\mathrm{T}$ cells pathway involved in immunosuppression. ${ }^{169}$

\section{Glucosidase inhibitors}

$\mathrm{N}$-glycosylation of viral glycoproteins is important in viral morphogenesis, and inhibition of glucosidase 1 activity adversely affects viral maturation. ${ }^{170}$ Celgosivir, a glucosidase 1 inhibitor, has shown synergy with interferon and ribavirin. ${ }^{170}$

\section{HCV-entry inhibitors}

Events occurring during virus replication trigger the exposure of normally intracellular anionic phospholipids on the outer surface of virus-infected cells. A chimeric antibody, bavituximab (antiphosphatidylserine), identifies and targets the exposed anionic phospholipids. ${ }^{171}$

\section{Activators of innate immunity/Toll-like receptor agonists}

Immunomodulatory approaches that are being studied include agonists of Toll-like receptors (TLR), which activate pathways of innate, cellular, and humoral immunity. $\mathrm{CpG}$ oligonucleotides, which contain motifs resembling bacterial DNA, activate TLR-9 expressed in plasmacytoid dendritic cells and B cells. ${ }^{172}$

\section{New interferons}

A novel recombinant protein that consists of interferonfused to human albumin (albumin interferon) is in phase 3 trial. This agent has an exceptionally long plasma half - life, which allows its administration every 2-4 weeks. In a study with 1131 treatment - naive patients, the SVR rate with albumin interferon (dose 900 or $1200 \mu \mathrm{g}$ every 2 weeks) was comparable with that of PEG-IFN $\alpha$-2a treatment $(48 \%$ and $51 \%$ vs $47 \%$ ).

Other potential advances in interferon therapy include the development of novel interferons (gene-shuffled interferons) such as BLX-883 (locteron interferon) and a new administration route that involves implantation of a subcutaneous device that releases interferon over several months. ${ }^{173}$

\section{Ribavirin pro-drugs}

Taribavirin is a prodrug that is converted to ribavirin and concentrated in the liver. In a phase III trial that compared treatment with either pegylated interferon PEG-IFN $\alpha 2 b$ in combination with taribavirin versus ribavirin, taribavirin failed to meet noninferiority criteria for efficacy although superior hematologic safety was demonstrated. ${ }^{174}$

\section{A new era in the therapy of recurrent hepatitis C?}

Although until now, to the best of our knowledge, there exist no clinical trials investigating STAT-C agents in patients who underwent LT for hepatitis C, these new drugs will offer efficient therapy to a wider patient group with better tolerability profiles and effectiveness in the near future. The introduction of targeted antiviral therapies for HCV and other new agents has the potential to lead to rapid viral clearance, increased SVR rates, and reduced duration of therapy. Earlier protease and polymerase inhibitors, and nucleic-based technology, have failed because of insufficient antiviral activity, or safety or delivery issues. Eventually some of the agents discussed here, or other promising approaches that are undergoing preclinical tests, will prove to be safe and effective. New rules for tailored HCV therapy will be established, facilitating highly individualized treatments that involve combinations of agents. It is certain that the new antiviral therapies will change treatment and viral kinetics before as well as after LT, especially for viral resistance. Moreover, side effects and treatment-induced anemia could affect therapeutic options of STAT-C in the transplant population.

So at this time it is too early to predict best therapeutic strategies of STAT-C or other drugs like cyclophilin inhibitors in this new era of HCV treatment in liver transplant patients with recurrent infection, possibly pretreated (or still under perioperative treatment?) with new agents. A combination of different treatment groups as well as perioperative treatment offer a number of possibilities, but the best therapeutic regimens need to be investigated and, so far, remain speculative. Overall the 
current studies in the nontransplant setting indicate that PEG alpha and ribavirin remain the backbone of antiviral therapy of chronic hepatitis $\mathrm{C}$ even in the era of STAT-C. Promising combinations are protease inhibitors plus nucleoside analogue and nonnucleoside analogue polymerase inhibitors.

\section{Conclusions}

Recurrent hepatitis $\mathrm{C}$ after LT is a major cause of morbidity and mortality in the post-transplant setting. The clinical course after LT is highly variable and accelerated compared to the pretransplant setting. Although many risk factors have been identified, their accuracy in predicting the course in individual patients is uncertain. Diagnosis is based upon the detection of HCV-RNA and compatible histologic changes. Optimal treatment of recurrence is not defined. Published data suggest that the best available therapy is a combination of PEG-IFN plus ribavirin in patients with established recurrent hepatitis $\mathrm{C}$ (fibrosis stages $\geq 2$ ) as proven by liver biopsy. Although increasing experience in using IFN therapy in the post-transplant setting has suggested better response rates, treatment is limited, especially after LT, by poor tolerability and high rates of severe side effects (mainly cytopenias), necessitating lower doses or withdrawal of therapy. The extent to which dose reductions affect SVR and the potential benefits of the concomitant administration of erythropoietin or granulocyte colony-stimulating factor in preventing complications or enhancing virological response is still to be determined. The optimal timing for the initiation of postLT antiviral therapy still needs to be defined. Prophylactic or preemptive therapy is limited by the low applicability and tolerability and low rates of virological response, and is therefore not recommended.

Clinical trials comparing the safety and efficacy of antiviral therapy initiated prophylactically vs treatment of recurrent hepatitis $\mathrm{C}$ are lacking.

The therapy should be carried out only in transplant centers with experience in managing hepatitis $\mathrm{C}$ after LT.

There are promising data suggesting that in future, new classes of antiviral drugs such as HCV protease inhibitors will improve HCV therapy after LT.

\section{Disclosures}

The authors declare no conflicts of interest.

\section{References}

1. Berenguer M, Lopez-Labrador FX, Wright TL. Hepatitis C and liver transplantation. J Hepatol. 2001;35(5):666-678.

2. Verna EC, Brown RS Jr. Hepatitis C virus and liver transplantation. Clin Liver Dis. 2006;10(4):919-940.
3. Gane E. The natural history and outcome of liver transplantation in hepatitis C virus-infected recipients. Liver Transpl. 2003;9(11): S28-S34.

4. Wright TL, Donegan E, Hsu HH, et al. Recurrent and acquired hepatitis C viral infection in liver transplant recipients. Gastroenterology. 1992;103(1):317-322.

5. Dickson RC, Caldwell SH, Ishitani MB, et al. Clinical and histologic patterns of early graft failure due to recurrnet hepatitis $\mathrm{C}$ in four patients after liver transplantation. Transplantation. 1996;61(5):701-705.

6. Garcia-Retortillo M, Forns X, Feliu A, et al. Hepatitis C virus kinetics during and immediately after liver transplantation. Hepatology. 2002;35(3):680-687.

7. Wiesner R, Rabkin J, Klintmalm G, et al. A randomized double-blind comparative study of mycophenolate mofetil and azathioprine in combination with cyclosporine and corticosteroids in primary liver transplant recipients. Liver Transpl. 2001;7(5):442-450.

8. Jain A, Kashyap R, Demetris AJ, Eghstesad B, Pokharna R, Fung JJ. A prospective randomized trial of mycophenolate mofetil in liver transplant recipients with hepatitis C. Liver Transpl. 2002;8(1):40-46.

9. Schluger LK, Sheiner PA, Thung SN, et al. Severe recurrent cholestatic hepatitis C following orthotopic liver transplantation. Hepatology. 1996;23(5):971-976.

10. Berenguer M, Ferrell L, Watson J, et al. HCV-related fibrosis progression following liver transplantation: increase in recent years. $J$ Hepatol. 2000;32(4):673-684.

11. Berenguer M, Prieto M, Rayon JM, et al. Natural history of clinically compensated hepatitis $\mathrm{C}$ virus-related graft cirrhosis after liver transplantation. Hepatology. 2000;32(4 Pt 1):852-858.

12. Forman LM, Lewis JD, Berlin JA, Feldman HI, Lucey MR. The association between hepatitis $\mathrm{C}$ infection and survival after orthotopic liver transplantation. Gastroenterology. 2002;122(4):889-896.

13. Thuluvath PJ, Krok KL, Segev DL, Yoo HY. Trends in post-liver transplant survival in patients with hepatitis C between 1991 and 2001 in the United States. Liver Transpl. 2007;13(5):719-724.

14. Berenguer M, Prieto M, San Juan F, et al. Contribution of donor age to the recent decrease in patient survival among HCV-infected liver transplant recipients. Hepatology. 2002;36(1):202-210.

15. Prieto M, Berenguer M, Rayon JM, et al. High incidence of allograft cirrhosis in hepatitis $\mathrm{C}$ virus genotype $1 \mathrm{~b}$ infection following transplantation: relationship with rejection episodes. Hepatology. 1999;29(1):250-256.

16. Berenguer M. Natural history of recurrent hepatitis C. Liver Transpl. 2002;8(10 Suppl 1):S14-S18.

17. Fattovich G, Giustina G, Degos F, et al. Morbidity and mortality in compensated cirrhosis type C: a retrospective follow-up study of 384 patients. Gastroenterology. 1997;112(2):463-472.

18. Gawrieh S, Papouchado BG, Burgart LJ, Kobayashi S, Charlton MR, Gores GJ. Early hepatic stellate cell activation predicts severe hepatitis $\mathrm{C}$ recurrence after liver transplantation. Liver Transpl. 2005;11(10):1207-1213.

19. Blasco A, Forns X, Carrion JA, et al. Hepatic venous pressure gradient identifies patients at risk of severe hepatitis $\mathrm{C}$ recurrence after liver transplantation. Hepatology. 2006;43(3):492-499.

20. Araya V, Rakela J, Wright T. Hepatitis C after orthotopic liver transplantation. Gastroenterology. 1997;112(2):575-582.

21. Gerlach JT, Diepolder HM, Jung MC, et al. Recurrence of hepatitis $\mathrm{C}$ virus after loss of virus-specific CD4+ T-cell response in acute hepatitis C. Gastroenterology. 1999;117(4):933-941.

22. Rosen HR, Hinrichs DJ, Gretch DR, et al. Association of multispecific CD4+ response to hepatitis $\mathrm{C}$ and severity of recurrence after liver transplantation. Gastroenterology. 1999;117(4):926-932.

23. Takaki A, Wiese M, Maertens G, et al. Cellular immune responses persist and humoral responses decrease two decades after recovery from a single-source outbreak of hepatitis C. Nat Med. 2000;6(5):578-582.

24. Lucas M, Ulsenheimer A, Pfafferot K, et al. Tracking virus-specific $\mathrm{CD} 4+\mathrm{T}$ cells during and after acute hepatitis $\mathrm{C}$ virus infection. PLoS One. 2007;2(7):e649. 
25. Schirren CA, Jung MC, Worzfeld T, et al. Hepatitis C virus-specific $\mathrm{CD} 4+\mathrm{T}$ cell response after liver transplantation occurs early, is multispecific, compartmentalizes to the liver, and does not correlate with recurrent disease. J Infect Dis. 2001;183(8):1187-1194.

26. Weston SJ, Leistikow RL, Reddy KR, et al. Reconstitution of hepatitis C virus-specific T-cellmediated immunity after liver transplantation. Hepatology. 2005;41(1):72-81.

27. Langrehr JM, Puhl G, Bahra M, et al. Influence of donor/recipient HLA-matching on outcome and recurrence of hepatitis $\mathrm{C}$ after liver transplantation. Liver Transpl. 2006;12(4):644-651.

28. Balan V, Ruppert K, Demetris AJ, et al. Long-term outcome of human leukocyte antigen mismatching in liver transplantation: results of the National Institute of Diabetes and Digestive and Kidney Diseases Liver Transplantation Database. Hepatology. 2008;48(3):878-888.

29. Rosen HR, Hinrichs DJ, Leistikow RL, et al. Cutting edge: identification of hepatitis C virus-specific CD8+ T cells restricted by donor HLA alleles following liver transplantation. J Immunol. 2004;173(9): 5355-5359.

30. Russo MW, Firpi RJ, Nelson DR, Schoonhoven R, Shrestha R, Fried MW. Early hepatic stellate cell activation is associated with advanced fibrosis after liver transplantation in recipients with hepatitis C. Liver Transpl. 2005;11(10):1235-1241.

31. Barber DL, Wherry EJ, Masopust D, et al. Restoring function in exhausted CD8+ T cells during chronic viral infection. Nature. 2006;439(7077):682-687.

32. Kasprowicz V, Schulze Zur Wiesch J, Kuntzen T, et al. High level of PD-1 expression on hepatitis C virus (HCV)-specific CD8+ and CD4+ $\mathrm{T}$ cells during acute $\mathrm{HCV}$ infection, irrespective of clinical outcome J Virol. 2008;82(6):3154-3160.

33. Urbani S, Amadei B, Tola D, et al. Restoration of HCV-specific T cell functions by PD-1/PD-L1 blockade in $\mathrm{HCV}$ infection: effect of viremia levels and antiviral treatment. J Hepatol. 2008;48(4):548-558.

34. Nakamoto N, Kaplan DE, Coleclough J, et al. Functional restoration of HCV-specific CD8+ T cells by PD-1 blockade is defined by PD-1 expression and compartmentalization. Gastroenterology. 2008;134(7):1927-37, 1937 e1-e2.

35. Zhao Y, Lo CM, Liu CL, Fan ST. Use of elderly donors ( $>60$ years) for liver transplantation. Asian J Surg. 2004;27(2):114-119.

36. Cameron AM, Ghobrial RM, Hiatt JR, et al. Effect of nonviral factors on hepatitis C recurrence after liver transplantation. Ann Surg. 2006;244(4):563-571.

37. Lake JR, Shorr JS, Steffen BJ, Chu AH, Gordon RD and Wiesner RH. Differential effects of donor age in liver transplant recipients infected with hepatitis B, hepatitis $\mathrm{C}$ and without viral hepatitis. Am JTransplant. 2005;5(3):549-557.

38. Burak KW, Kremers WK, Batts KP, et al. Impact of cytomegalovirus infection, year of transplantation, and donor age on outcomes after liver transplantation for hepatitis C. Liver Transpl. 2002;8(4):362-369.

39. Berenguer M, Crippin J, Gish R, et al. A model to predict severe HCV-related disease following liver transplantation. Hepatology. 2003;38(1):34-41.

40. Gane EJ, Portmann BC, Naoumov NV, et al. Long-term outcome of hepatitis C infection after liver transplantation. $N$ Engl $J$ Med. 1996;334(13):815-820.

41. Vargas HE, Laskus T, Wang LF, et al. The influence of hepatitis $C$ virus genotypes on the outcome of liver transplantation. Liver Transpl Surg. 1998;4(1):22-27.

42. Gaglio PJ, Malireddy S, Levitt BS, et al. Increased risk of cholestatic hepatitis $\mathrm{C}$ in recipients of grafts from living versus cadaveric liver donors. Liver Transpl. 2003;9(10):1028-1035.

43. Garcia-Retortillo M, Forns X, Llovet JM, et al. Hepatitis C recurrence is more severe after living donor compared to cadaveric liver transplantation. Hepatology. 2004;40(3):699-707.

44. Russo MW, Galanko J, Beavers K, Fried MW, Shrestha R. Patient and graft survival in hepatitis $\mathrm{C}$ recipients after adult living donor liver transplantation in the United States. Liver Transpl. 2004;10(3): $340-346$
45. Shiffman ML, Stravitz RT, Contos MJ, et al. Histologic recurrence of chronic hepatitis $\mathrm{C}$ virus in patients after living donor and deceased donor liver transplantation. Liver Transpl. 2004;10(10):1248-1255.

46. Stravitz RT, Shiffman ML, Sanyal AJ, et al. Effects of interferon treatment on liver histology and allograft rejection in patients with recurrent hepatitis $\mathrm{C}$ following liver transplantation. Liver Transpl. 2004;10(7):850-858.

47. Schiano TD, Gutierrez JA, Walewski JL, et al. Accelerated hepatitis C virus kinetics but similar survival rates in recipients of liver grafts from living versus deceased donors. Hepatology. 2005;42(6):1420-1428.

48. Guo L, Orrego M, Rodriguez-Luna H, et al. Living donor liver transplantation for hepatitis C-related cirrhosis: no difference in histological recurrence when compared to deceased donor liver transplantation recipients. Liver Transpl. 2006;12(4):560-565.

49. Takada $\mathrm{Y}$, Haga H, Ito T, et al. Clinical outcomes of living donor liver transplantation for hepatitis $\mathrm{C}$ virus (HCV)-positive patients. Transplantation. 2006;81(3):350-354.

50. Schmeding M, Neumann UP, Puhl G, Bahra M, Neuhaus R, Neuhaus P. Hepatitis $\mathrm{C}$ recurrence and fibrosis progression are not increased after living donor liver transplantation: a single-center study of 289 patients. Liver Transpl. 2007;13(5):687-692.

51. Terrault NA, Shiffman ML, Lok AS, et al. Outcomes in hepatitis C virus-infected recipients of living donor vs. deceased donor liver transplantation. Liver Transpl. 2007;13(1):122-129.

52. Feray C, Gigou M, Samuel D, et al. Influence of the genotypes of hepatitis $\mathrm{C}$ virus on the severity of recurrent liver disease after liver transplantation. Gastroenterology. 1995;108(4):1088-1096.

53. Gordon FD, Poterucha JJ, Germer J, et al. Relationship between hepatitis $\mathrm{C}$ genotype and severity of recurrent hepatitis $\mathrm{C}$ after liver transplantation. Transplantation. 1997;63(10):1419-1423.

54. Charlton M, Seaberg E, Wiesner R, et al. Predictors of patient and graft survival following liver transplantation for hepatitis C. Hepatology. 1998;28(3):823-830.

55. Feray C, Caccamo L, Alexander GJ, et al. European collaborative study on factors influencing outcome after liver transplantation for hepatitis C. European Concerted Action on Viral Hepatitis (EUROHEP) Group. Gastroenterology. 1999;117(3):619-625.

56. Pessoa MG, Bzowej N, Berenguer M, et al. Evolution of hepatitis C virus quasispecies in patients with severe cholestatic hepatitis after liver transplantation. Hepatology. 1999;30(6):1513-1520.

57. Gane EJ, Naoumov NV, Qian KP, et al. A longitudinal analysis of hepatitis $\mathrm{C}$ virus replication following liver transplantation. Gastroenterology. 1996;110(1):167-177.

58. Feray C, Gigou M, Samuel D, et al. The course of hepatitis C virus infection after liver transplantation. Hepatology. 1994;20(5):1137-1143.

59. McCaughan GW, Zekry A. Pathogenesis of hepatitis $\mathrm{C}$ virus recurrence in the liver allograft. Liver Transpl. 2002;8(10 Suppl 1):S7-S13.

60. McCaughan GW, Zekry A. Mechanisms of HCV reinfection and allograft damage after liver transplantation. J Hepatol. 2004;40(3):368-374.

61. Hunt J, Gordon FD, Lewis WD, et al. Histological recurrence and progression of hepatitis $\mathrm{C}$ after orthotopic liver transplantation: influence of immunosuppressive regimens. Liver Transpl. 2001;7(12):1056-1063.

62. Sreekumar R, Gonzalez-Koch A, Maor-KendlerY, et al. Early identification of recipients with progressive histologic recurrence of hepatitis $\mathrm{C}$ after liver transplantation. Hepatology. 2000;32(5):1125-1130.

63. Deshpande V, Burd E, Aardema KL, et al. High levels of hepatitis C virus RNA in native livers correlate with the development of cholestatic hepatitis in liver allografts and a poor outcome. Liver Transpl. 2001;7(2):118-124.

64. Nelson DR, Soldevila-Pico C, Reed A, et al. Anti-interleukin-2 receptor therapy in combination with mycophenolate mofetil is associated with more severe hepatitis $\mathrm{C}$ recurrence after liver transplantation. Liver Transpl. 2001;7(12):1064-1070.

65. Charlton M and Seaberg E. Impact of immunosuppression and acute rejection on recurrence of hepatitis C: results of the National Institute of Diabetes and Digestive and Kidney Diseases Liver Transplantation Database. Liver Transpl Surg. 1999;5(4 Suppl 1):S107-S114. 
66. Papatheodoridis GV, Davies S, Dhillon AP, et al. The role of different immunosuppression in the long-term histological outcome of HCV reinfection after liver transplantation for HCV cirrhosis. Transplantation. 2001;72(3):412-418.

67. Charlton M. Genotype $1 \mathrm{~b}$ and severity of posttransplant recurrence of hepatitis $\mathrm{C}$ infection- unconvictable felon or wrongly accused? Liver Transpl. 2000;6(2):243-245.

68. Berenguer M, Aguilera V, Prieto M, et al. Effect of calcineurin inhibitors on survival and histologic disease severity in HCV-infected liver transplant recipients. Liver Transpl. 2006;12(5):762-767.

69. Firpi RJ, Zhu H, Morelli G, et al. Cyclosporine suppresses hepatitis C virus in vitro and increases the chance of a sustained virological response after liver transplantation. Liver Transpl. 2006;12(1):51-57.

70. Berenguer M, Aguilera V, Prieto M, et al. Significant improvement in the outcome of HCV-infected transplant recipients by avoiding rapid steroid tapering and potent induction immunosuppression. J Hepatol. 2006;44(4):717-722.

71. Brillanti S, Vivarelli M, De Ruvo N, et al. Slowly tapering off steroids protects the graft against hepatitis $\mathrm{C}$ recurrence after liver transplantation. Liver Transpl. 2002;8(10):884-888.

72. Nakagawa M, Sakamoto N, Enomoto N, et al. Specific inhibition of hepatitis $\mathrm{C}$ virus replication by cyclosporin A. Biochem Biophys Res Commun. 2004;313(1):42-47.

73. Watashi K, Hijikata M, Hosaka M, Yamaji M, Shimotohno K. Cyclosporin A suppresses replication of hepatitis $\mathrm{C}$ virus genome in cultured hepatocytes. Hepatology. 2003;38(5):1282-1288.

74. Wiesner RH, Shorr JS, Steffen BJ, Chu AH, Gordon RD, Lake JR. Mycophenolate mofetil combination therapy improves long-term outcomes after liver transplantation in patients with and without hepatitis $\mathrm{C}$. Liver Transpl. 2005;11(7):750-759.

75. Segev DL, Sozio SM, Shin EJ, et al. Steroid avoidance in liver transplantation: meta-analysis and meta-regression of randomized trials. Liver Transpl. 2008;14(4):512-525.

76. Llado L, Fabregat J, Castellote J, et al. Impact of immunosuppression without steroids on rejection and hepatitis $\mathrm{C}$ virus evolution after liver transplantation: results of a prospective randomized study. Liver Transpl. 2008;14(12):1752-1760.

77. Kato T, Gaynor JJ, Yoshida H, et al. Randomized trial of steroid-free induction versus corticosteroid maintenance among orthotopic liver transplant recipients with hepatitis $\mathrm{C}$ virus: impact on hepatic fibrosis progression at one year. Transplantation. 2007;84(7):829-835.

78. Becker T, Foltys D, Bilbao I, et al. Patient outcomes in two steroid-free regimens using tacrolimus monotherapy after daclizumab induction and tacrolimus with mycophenolate mofetil in liver transplantation. Transplantation. 2008;86(12):1689-1694.

79. Fried MW, Shiffman ML, Reddy KR, et al. Peginterferon alfa-2a plus ribavirin for chronic hepatitis $\mathrm{C}$ virus infection. $N$ Engl J Med. 2002;347(13):975-982.

80. Samuel D, Feray C. Recurrence of hepatitis C virus infection after liver transplantation. J Hepatol. 1999;31 Suppl 1:217-2121.

81. Di Martino V, Saurini F, Samuel D, et al. Long-term longitudinal study of intrahepatic hepatitis $\mathrm{C}$ virus replication after liver transplantation. Hepatology. 1997;26(5):1343-1350.

82. Pelletier SJ, Raymond DP, Crabtree TD, et al. Hepatitis C-induced hepatic allograft injury is associated with a pretransplantation elevated viral replication rate. Hepatology. 2000;32(2):418-426.

83. Poynard T, Marcellin P, Lee SS, et al. Randomised trial of interferon alpha2b plus ribavirin for 48 weeks or for 24 weeks versus interferon alpha2b plus placebo for 48 weeks for treatment of chronic infection with hepatitis C virus. International Hepatitis Interventional Therapy Group (IHIT). Lancet. 1998;352(9138):1426-1432.

84. Feray C, Samuel D, Gigou M, et al. An open trial of interferon alfa recombinant for hepatitis $\mathrm{C}$ after liver transplantation: antiviral effects and risk of rejection. Hepatology. 1995;22(4 Pt 1):1084-1089.

85. Dousset B, Conti F, Houssin D, Calmus Y. Acute vanishing bile duct syndrome after interferon therapy for recurrent $\mathrm{HCV}$ infection in livertransplant recipients. N Engl J Med. 1994;330(16):1160-1161.
86. Gadano AC, Mosnier JF, Durand F, et al. alpha-Interferon-induced rejection of a hepatitis $\mathrm{C}$ virus-infected liver allograft tolerated with a low dosage immunosuppressive regimen. Transplantation. 1995;59(11):1627-1629.

87. Bizollon T, Pradat P, Mabrut JY, et al. Benefit of sustained virological response to combination therapy on graft survival of liver transplanted patients with recurrent chronic hepatitis C. Am J Transplant. 2005;5(8):1909-1913.

88. Picciotto FP, Tritto G, Lanza AG, et al. Sustained virological response to antiviral therapy reduces mortality in $\mathrm{HCV}$ reinfection after liver transplantation. J Hepatol. 2007;46(3):459-465.

89. Berenguer M. Treatment of hepatitis $\mathrm{C}$ after liver transplantation. Clin Liver Dis. 2005;9(4):579-600, vi.

90. Samuel D, Forns X, Berenguer M, et al. Report of the monothematic EASL conference on liver transplantation for viral hepatitis (Paris, France, January 12-14, 2006). J Hepatol. 2006;45(1):127-143.

91. Lavezzo B, Franchello A, Smedile A, et al. Treatment of recurrent hepatitis $\mathrm{C}$ in liver transplants: efficacy of a six versus a twelve month course of interferon alfa 2 b with ribavirin. J Hepatol. 2002;37(2): 247-252.

92. Samuel D, Bizollon T, Feray C, et al. Interferon-alpha $2 b$ plus ribavirin in patients with chronic hepatitis $\mathrm{C}$ after liver transplantation: a randomized study. Gastroenterology. 2003;124(3):642-650.

93. Ross AS, Bhan AK, Pascual M, Thiim M, Benedict Cosimi A and Chung RT. Pegylated interferon alpha-2b plus ribavirin in the treatment of post-liver transplant recurrent hepatitis C. Clin Transplant. 2004;18(2):166-173.

94. Dumortier J, Scoazec JY, Chevallier P, Boillot O. Treatment of recurrent hepatitis $\mathrm{C}$ after liver transplantation: a pilot study of peginterferon alfa-2b and ribavirin combination. J Hepatol. 2004;40(4):669-674.

95. Rodriguez-Luna H, Khatib A, Sharma P, et al. Treatment of recurrent hepatitis $\mathrm{C}$ infection after liver transplantation with combination of pegylated interferon alpha $2 \mathrm{~b}$ and ribavirin: an open-label series. Transplantation. 2004;77(2):190-194.

96. Neff GW, Montalbano M, O`Brien CB, et al. Treatment of established recurrent hepatitis $\mathrm{C}$ in liver-transplant recipients with pegylated interferon-alfa-2b and ribavirin therapy. Transplantation. 2004;78(9):1303-1307.

97. Montalbano M, Neff GW, Yamashiki N, et al. A retrospective review of liver transplant patients treated with sirolimus from a single center: an analysis of sirolimus-related complications. Transplantation. 2004;78(2):264-268.

98. Toniutto P, Fabris C, Fumo E, et al. Pegylated versus standard interferon-alpha in antiviral regimens for post-transplant recurrent hepatitis C: Comparison of tolerability and efficacy. J Gastroenterol Hepatol. 2005;20(4):577-582.

99. Babatin M, Schindel L, Burak KW. Pegylated-interferon alpha 2b and ribavirin for recurrent hepatitis $\mathrm{C}$ after liver transplantation: From a Canadian experience to recommendations for therapy. Can J Gastroenterol. 2005;19(6):359-365.

100. Biselli M, Andreone P, Gramenzi A, et al. Pegylated interferon plus ribavirin for recurrent Hepatitis $\mathrm{C}$ infection after liver transplantation in naive and non-responder patients on a stable immunosuppressive regimen. Dig Liver Dis. 2006;38(1):27-32.

101. Berenguer M, Palau A, Fernandez A, et al. Efficacy, predictors of response, and potential risks associated with antiviral therapy in liver transplant recipients with recurrent hepatitis C. Liver Transpl. 2006;12(7):1067-1076.

102. Oton E, Barcena R, Moreno-Planas JM, et al. Hepatitis C recurrence after liver transplantation: Viral and histologic response to full-dose PEGinterferon and ribavirin. Am J Transplant. 2006;6(10):2348-2355.

103. Mukherjee S, Lyden E. Impact of pegylated interferon alpha-2B and ribavirin on hepatic fibrosis in liver transplant patients with recurrent hepatitis C: an open-label series. Liver Int. 2006;26(5):529-535.

104. Fernandez I, Meneu JC, Colina F, et al. Clinical and histological efficacy of pegylated interferon and ribavirin therapy of recurrent hepatitis $\mathrm{C}$ after liver transplantation. Liver Transpl. 2006;12(12):1805-1812. 
105. Neumann U, Puhl G, Bahra M, et al. Treatment of patients with recurrent hepatitis $\mathrm{C}$ after liver transplantation with peginterferon alfa-2B plus ribavirin. Transplantation. 2006;82(1):43-47.

106. Castells L, Vargas V, Allende H, et al. Combined treatment with pegylated interferon (alpha-2b) and ribavirin in the acute phase of hepatitis $\mathrm{C}$ virus recurrence after liver transplantation. $J$ Hepatol. 2005;43(1):53-59.

107. Sharma P, Marrero JA, Fontana RJ, et al. Sustained virologic response to therapy of recurrent hepatitis $\mathrm{C}$ after liver transplantation is related to early virologic response and dose adherence. Liver Transpl. 2007;13(8):1100-1108.

108. Zimmermann T, Bocher WO, Biesterfeld S, et al. Efficacy of an escalating dose regimen of pegylated interferon alpha-2a plus ribavirin in the early phase of HCV reinfection after liver transplantation. Transpl Int. 2007;20(7):583-590.

109. Angelico M, Petrolati A, Lionetti R, et al. A randomized study on Peginterferon alfa-2a with or without ribavirin in liver transplant recipients with recurrent hepatitis C. J Hepatol. 2007;46(6):1009-1017.

110. Carrion JA, Navasa M, Garcia-Retortillo M, et al. Efficacy of antiviral therapy on hepatitis $\mathrm{C}$ recurrence after liver transplantation: a randomized controlled study. Gastroenterology. 2007;132(5):1746-1756.

111. Mukherjee S, Lyden E. Impact of pegylated interferon alfa-2a and ribavirin on hepatic fibrosis in liver transplant patients with recurrent hepatitis C: an open-label series. Hepatogastroenterology. 2006;53(70):561-565.

112. Strader DB, Wright T, Thomas DL, Seeff LB. Diagnosis, management, and treatment of hepatitis C. Hepatology. 2004;39(4):1147-1171.

113. Ghany MG, Strader DB, Thomas DL, Seeff LB. Diagnosis, management, and treatment of hepatitis $\mathrm{C}$ : an update. Hepatology. 2009;49(4):1335-1374.

114. Zeuzem S, Berg T, Moeller B, et al. Expert opinion on the treatment of patients with chronic hepatitis C. J Viral Hepat. 2009;16(2):75-90.

115. Crippin JS, McCashland T, Terrault N, Sheiner P and Charlton MR. A pilot study of the tolerability and efficacy of antiviral therapy in hepatitis $\mathrm{C}$ virus-infected patients awaiting liver transplantation. Liver Transpl. 2002;8(4):350-355.

116. Everson GT. Treatment of chronic hepatitis $\mathrm{C}$ in patients with decompensated cirrhosis. Rev Gastroenterol Disord. 2004;4 Suppl 1: S31-S38.

117. Everson GT, Trotter J, Forman L, et al. Treatment of advanced hepatitis $\mathrm{C}$ with a low accelerating dosage regimen of antiviral therapy. Hepatology. 2005;42(2):255-262.

118. Wiesner RH, Sorrell M, Villamil F. Report of the first International Liver Transplantation Society expert panel consensus conference on liver transplantation and hepatitis C. Liver Transpl. 2003;9(11):S1-S9.

119. Feray C, Gigou M, Samuel D, et al. Incidence of hepatitis C in patients receiving different preparations of hepatitis B immunoglobulins after liver transplantation. Ann Intern Med. 1998;128(10):810-816.

120. Davis GL, Nelson DR, Terrault N, et al. A randomized, open-label study to evaluate the safety and pharmacokinetics of human hepatitis C immune globulin (Civacir) in liver transplant recipients. Liver Transpl. 2005;11(8):941-949.

121. Zhang P, Wu CG, Mihalik K, et al. Hepatitis C virus epitope-specific neutralizing antibodies in Igs prepared from human plasma. Proc Natl Acad Sci U S A. 2007;104(20):8449-8454.

122. Kaplan M, Gawrieh S, Cotler SJ, Jensen DM. Neutralizing antibodies in hepatitis $\mathrm{C}$ virus infection: a review of immunological and clinical characteristics. Gastroenterology. 2003;125(2):597-604.

123. Singh N, Gayowski T, Wannstedt CF, et al. Interferon-alpha for prophylaxis of recurrent viral hepatitis $\mathrm{C}$ in liver transplant recipients: a prospective, randomized, controlled trial. Transplantation. 1998;65(1):82-86.

124. Sheiner PA, Boros P, Klion FM, et al. The efficacy of prophylactic interferon alfa- $2 \mathrm{~b}$ in preventing recurrent hepatitis $\mathrm{C}$ after liver transplantation. Hepatology. 1998;28(3):831-838.

125. Cotler SJ, Ganger DR, Kaur S, et al. Daily interferon therapy for hepatitis $\mathrm{C}$ virus infection in liver transplant recipients. Transplantation. 2001;71(2):261-266.
126. Mazzaferro V, Tagger A, Schiavo M, et al. Prevention of recurrent hepatitis $\mathrm{C}$ after liver transplantation with early interferon and ribavirin treatment. Transplant Proc. 2001;33(1-2):1355-1357.

127. Chalasani N, Manzarbeitia C, Ferenci P, et al. Peginterferon alfa-2a for hepatitis $\mathrm{C}$ after liver transplantation: two randomized, controlled trials. Hepatology. 2005;41(2):289-298.

128. Shergill AK, Khalili M, Straley S, et al. Applicability, tolerability and efficacy of preemptive antiviral therapy in hepatitis C-infected patients undergoing liver transplantation. Am J Transplant. 2005;5(1): $118-124$.

129. Sugawara Y, Makuuchi M, Matsui Y, et al. Preemptive therapy for hepatitis $\mathrm{C}$ virus after living-donor liver transplantation. Transplantation. 2004;78(9):1308-1311.

130. Gordon FD, Kwo P, Vargas HE. Treatment of hepatitis C in liver transplant recipients. Liver Transpl. 2009;15(2):126-135.

131. Berenguer M. Systematic review of the treatment of established recurrent hepatitis $\mathrm{C}$ with pegylated interferon in combination with ribavirin. J Hepatol. 2008;49(2):274-287.

132. Gurusamy KS, Osmani B, Xirouchakis E, Burroughs AK, Davidson BR. Antiviral therapy for recurrent liver graft infection with hepatitis C virus. Cochrane Database Syst Rev. 2009; (1): CD006803.

133. Wright TL, Combs C, Kim M, et al. Interferon-alpha therapy for hepatitis $\mathrm{C}$ virus infection after liver transplantation. Hepatology. 1994;20(4 Pt 1):773-779.

134. Gane EJ, Lo SK, Riordan SM, et al. A randomized study comparing ribavirin and interferon alfa monotherapy for hepatitis $\mathrm{C}$ recurrence after liver transplantation. Hepatology. 1998;27(5):1403-1407.

135. Boillot O, Berger F, Rasolofo E, et al. Effectiveness of early alphainterferon therapy for hepatitis $\mathrm{C}$ virus infection recurrence after liver transplantation. Transpl Int. 1996;9 Suppl 1:S202-S203.

136. Gane EJ, Tibbs CJ, Ramage JK, Portmann BC, Williams R. Ribavirin therapy for hepatitis $\mathrm{C}$ infection following liver transplantation. Transpl Int. 1995;8(1):61-64.

137. Cattral MS, Hemming AW, Wanless IR, et al. Outcome of long-term ribavirin therapy for recurrent hepatitis $\mathrm{C}$ after liver transplantation. Transplantation. 1999;67(9):1277-1280.

138. Bizollon T, Palazzo U, Ducerf C, et al. Pilot study of the combination of interferon alfa and ribavirin as therapy of recurrent hepatitis $\mathrm{C}$ after liver transplantation. Hepatology. 1997;26(2):500-504.

139. Ahmad J, Dodson SF, Demetris AJ, Fung JJ, Shakil AO. Recurrent hepatitis $\mathrm{C}$ after liver transplantation: a nonrandomized trial of interferon alfa alone versus interferon alfa and ribavirin. Liver Transpl. 2001;7(10):863-869

140. Narayanan Menon KV, Poterucha JJ, El-Amin OM, et al. Treatment of posttransplantation recurrence of hepatitis $\mathrm{C}$ with interferon and ribavirin: lessons on tolerability and efficacy. Liver Transpl. 2002;8(7):623-629.

141. Alberti AB, Belli LS, Airoldi A, et al. Combined therapy with interferon and low-dose ribavirin in posttransplantation recurrent hepatitis C: a pragmatic study. Liver Transpl. 2001;7(10):870-876.

142. Firpi RJ, Abdelmalek MF, Soldevila-Pico C, et al. Combination of interferon alfa-2b and ribavirin in liver transplant recipients with histological recurrent hepatitis C. Liver Transpl. 2002;8(11):1000-1006.

143. Shakil AO, McGuire B, Crippin J, et al. A pilot study of interferon alfa and ribavirin combination in liver transplant recipients with recurrent hepatitis C. Hepatology. 2002;36(5):1253-1258.

144. Nair S, Khan S, Loss G, et al. Treatment of recurrent hepatitis C in liver transplant recipients: is there any histologic benefit? Liver Transpl. 2003;9(4):354-359.

145. Beckebaum S, Cicinnati VR, Zhang X, et al. Combination therapy with peginterferon alpha-2B and ribavirin in liver transplant recipients with recurrent $\mathrm{HCV}$ infection: preliminary results of an open prospective study. Transplant Proc. 2004;36(5):1489-1491.

146. Moreno Planas JM, Rubio Gonzalez E, Boullosa Grana E, et al. Peginterferon and ribavirin in patients with HCV cirrhosis after liver transplantation. Transplant Proc. 2005;37(5):2207-2208. 
147. Wang CS, Ko HH, Yoshida EM, Marra CA, Richardson K. Interferon-based combination anti-viral therapy for hepatitis $\mathrm{C}$ virus after liver transplantation: a review and quantitative analysis. $\mathrm{Am} \mathrm{J}$ Transplant. 2006;6(7):1586-1599.

148. Bizollon T, Ahmed SN, Radenne S, et al. Long term histological improvement and clearance of intrahepatic hepatitis $\mathrm{C}$ virus RNA following sustained response to interferon-ribavirin combination therapy in liver transplanted patients with hepatitis $\mathrm{C}$ virus recurrence. Gut. 2003;52(2):283-287.

149. Berenguer M, Prieto M, Palau A, et al. Recurrent hepatitis C genotype $1 \mathrm{~b}$ following liver transplantation: treatment with combination interferon-ribavirin therapy. Eur J Gastroenterol Hepatol. 2004;16(11):1207-1212.

150. Berenguer M, Palau A, Aguilera V, Rayon JM, Juan FS, Prieto M. Clinical benefits of antiviral therapy in patients with recurrent hepatitis $\mathrm{C}$ following liver transplantation. Am J Transplant. 2008;8(3):679-687.

151. Hanouneh IA, Feldstein AE, McCullough AJ, et al. The significance of metabolic syndrome in the setting of recurrent hepatitis $\mathrm{C}$ after liver transplantation. Liver Transpl. 2008;14(9):1287-1293.

152. Adinolfi LE, Gambardella M, Andreana A, Tripodi MF, Utili R and Ruggiero G. Steatosis accelerates the progression of liver damage of chronic hepatitis $\mathrm{C}$ patients and correlates with specific HCV genotype and visceral obesity. Hepatology. 2001;33(6):1358-1364.

153. Neff GW, O`Brien CB, Nery J, et al. Factors that identify survival after liver retransplantation for allograft failure caused by recurrent hepatitis C infection. Liver Transpl. 2004;10(12):1497-503.

154. Biggins SW, Beldecos A, Rabkin JM, Rosen HR. Retransplantation for hepatic allograft failure: prognostic modeling and ethical considerations. Liver Transpl. 2002;8(4):313-322.

155. Sheiner PA, Schluger LK, Emre S, et al. Retransplantation for recurrent hepatitis C. Liver Transpl Surg. 1997;3(2):130-136.

156. Rosen HR, O`Reilly PM, Shackleton CR, et al. Graft loss following liver transplantation in patients with chronic hepatitis C. Transplantation. 1996;62(12):1773-1776.

157. Berenguer M, Prieto M, Palau A, et al. Severe recurrent hepatitis C after liver retransplantation for hepatitis $\mathrm{C}$ virus-related graft cirrhosis. Liver Transpl. 2003;9(3):228-235.

158. Roayaie S, Schiano TD, Thung SN, et al. Results of retransplantation for recurrent hepatitis C. Hepatology. 2003;38(6):1428-1436.

159. Alamo JM, Gomez MA, Pareja F, et al. Morbidity and mortality in liver retransplantation. Transplant Proc. 2006;38(8):2475-2477.

160. McCashland T, Watt K, Lyden E, et al. Retransplantation for hepatitis C: results of a U.S. multicenter retransplant study. Liver Transpl. 2007;13(9):1246-1253.

161. Hanouneh IA, Miller C, Aucejo F, Lopez R, Quinn MK, Zein NN. Recurrent hepatitis $\mathrm{C}$ after liver transplantation: on-treatment prediction of response to peginterferon/ribavirin therapy. Liver Transpl. 2008;14(1):53-58.
162. McHutchison JG, Dusheiko G, Shiffman ML, et al. Eltrombopag for thrombocytopenia in patients with cirrhosis associated with hepatitis C. N Engl J Med. 2007;357(22):2227-2236.

163. Mukherjee S, Rogge J, Weaver LK, Schafer DF. De novo cryptogenic hepatitis after sustained eradication of hepatitis $\mathrm{C}$ following liver transplantation. Transplant Proc. 2004;36(5):1494-1497.

164. Kontorinis N, Agarwal K, Elhajj N, Fiel MI, Schiano TD. Pegylated interferon-induced immune-mediated hepatitis post-liver transplantation. Liver Transpl. 2006;12(5):827-830.

165. Dan AA, Martin LM, Crone C, et al. Depression, anemia and health-related quality of life in chronic hepatitis C. J Hepatol. 2006;44(3):491-498.

166. Reesink HW, Zeuzem S, Weegink CJ, et al. Rapid decline of viral RNA in hepatitis C patients treated with VX-950: a phase Ib, placebocontrolled, randomized study. Gastroenterology. 2006;131(4): 997-1002.

167. Hezode C, Forestier N, Dusheiko G, et al. Telaprevir and peginterferon with or without ribavirin for chronic $\mathrm{HCV}$ infection. $N$ Engl J Med. 2009;360(18):1839-1850.

168. McHutchison JG, Everson GT, Gordon SC, et al. Telaprevir with peginterferon and ribavirin for chronic HCV genotype 1 infection. N Engl J Med. 2009;360(18):1827-1838.

169. Paeshuyse J, Kaul A, De Clercq E, et al. The non-immunosuppressive cyclosporin DEBIO-025 is a potent inhibitor of hepatitis $\mathrm{C}$ virus replication in vitro. Hepatology. 2006;43(4):761-770.

170. Whitby K, Taylor D, Patel D, Ahmed P, Tyms AS. Action of celgosivir (6 O-butanoyl castanospermine) against the pestivirus BVDV: implications for the treatment of hepatitis C. Antivir Chem Chemother. 2004;15(3):141-151.

171. Soares MM, King SW, Thorpe PE. Targeting inside-out phosphatidylserine as a therapeutic strategy for viral diseases. Nat Med. 2008;14(12):1357-1362.

172. Gupta K, Cooper C. A review of the role of $\mathrm{CpG}$ oligodeoxynucleotides as toll-like receptor 9 agonists in prophylactic and therapeutic vaccine development in infectious diseases. Drugs $R$ D. 2008;9(3):137-145.

173. De Leede LG, Humphries JE, Bechet AC, Van Hoogdalem EJ, Verrijk R, Spencer DG. Novel controlled-release Lemna-derived IFN-alpha2b (Locteron): pharmacokinetics, pharmacodynamics, and tolerability in a phase I clinical trial. J Interferon Cytokine Res. 2008;28(2):113-122.

174. Benhamou Y, Afdhal NH, Nelson DR, et al. A phase III study of the safety and efficacy of viramidine versus ribavirin in treatment-naive patients with chronic hepatitis C: ViSER1 results. Hepatology. 2009 May 11. [Epub ahead of print].
Transplant Research and Risk Management

\section{Publish your work in this journal}

Transplant Research and Risk Management is an international, peerreviewed open access journal focusing on all aspects of transplantation and risk management to achieve optimal outcomes in the recipient improving survival and quality of life. The journal welcomes submitted papers covering original research, basic science, clinical studies,

\section{Dovepress}

reviews \& evaluations, guidelines, expert opinion and commentary, case reports and extended reports. The manuscript management system is completely online and includes a very quick and fair peer-review system, which is all easy to use. Visit http://www.dovepress.com/ testimonials.php to read real quotes from published authors. 